\title{
Is the Modern High Potential Dairy Cow Suitable for Organic Farming Conditions?
}

\author{
By Grétar H. Harðarson
}

Agricultural Research Institute, Stóra Ármót-Experimental Station, Austurvegi 1, IS-800 Selfoss.

\begin{abstract}
It is not acceptable to compromise animal welfare in any system of farming. Feeding should be aimed at meeting the nutritional requirements at the various stages of production. This paper deals with the detrimental effects that organic, extensive or low input farming systems may have on the energy status in early lactation of the high potential dairy cow. Bovine ketosis is the most important disease resulting from insufficient energy intake in early lactation. It is also important to realize that ketosis is a part of the so-called periparturient disease complex, which includes milk fever, mastitis, retained placenta, endometritis and poor fertility also. All these diseases are interrelated and reflect to a large extent the nutritional status of the animal. If organic dairy farming is to be successful the breeding programmes have to divert from selection for high yields as a main goal, to more emphasis on a flatter lactation curve, less production diseases and longevity.
\end{abstract}

Dairy cow, feeding, energy metabolism, bovine ketosis, periparturient disease, organic farming, welfare, voluntary food intake.

\section{Introduction}

There are only three organic dairy farms in Iceland, while conventional dairy farms are about eleven hundred. It is difficult to say why organic dairy farming has not yet gained any popularity in Iceland. The most obvious reason may be that the price of milk to the farmer producing milk in the conventional system is fairly high so there is not the same economic drive as in many countries where the farmers are experiencing a constant drop in milk prices. There is no scientific research carried out in organic dairy farming in Iceland so this paper does not present original scientific results. It is a general discussion about welfare, energy metabolism and the difficulties the organic dairy farmer is faced with in early lactation.

\section{Welfare}

It is one of the most important roles of veterinary practitioners to ensure the welfare of ani- mals committed to his or her care. However, animal welfare is difficult to define. Many regulations deal with prevention of cruelty to animals in order to assist animal owners in feeding and management of their animals.

The question is, how does the modern dairy cow, which has been bred for high milk production as a main goal for decades react to the conditions for organic production laid down by the International Federation of Organic Agriculture Movement (IFOAM)?

In an attempt to fulfil the welfare conditions of dairy cattle the organic and the conventional farming practices differ as far as some aspects are concerned. The most obvious differences are in the feeding practices and veterinary treatments. The other conditions concerning housing, husbandry, transport and identification are easier to fulfil in both systems. The introduction of organic principles into dairy farming has 
both provoked criticism on the grounds of animal welfare (Andrews 1991) and lead to ambitious research work into the health status and welfare of dairy cattle kept under organic farming conditions (Vaarst 1995, Weller \& Cooper 1996, Ebbesvik 1993, Von Weber et al. 1993). In the Council Regulation (EC) No 1804/1999 says: "Feed is intended to ensure quality production rather than maximising production, while meeting the nutritional requirements of the livestock at various stages of their development..."

\section{The metabolic load in early lactation:}

At the onset of lactation there is a massive and rapid increase in nutritional requirements, which the dairy cow is unable to meet because of the limitation in voluntary dry matter intake. Hence we get mobilization of body reserves. The question is when does the metabolic load involved in fat mobilization lead to a stressful situation and reduced welfare? Clearly we don't have a cut-off point between good and bad welfare. The diagram in Fig. 1 is a simplistic presentation of the effects of metabolic load. Below a certain level of metabolic load the animal is not challenged; even at high intensity of metabolic load the animal remains largely unchallenged provided that the duration is short and vice versa. When the metabolic load reaches a level where it becomes challenging, the animal will attempt to cope by behavioural and physiological response. Further increases in metabolic load will leave the animal unable to cope and will lead to pathological response. (Nielsen \& Lawrence 1996). In the context of energy deficiency in early lactation we could define pathological response when the concentration of ketone bodies in blood is raised above a certain level e.g. levels of $\beta$-hydroxybutyrate above $1 \mathrm{mmol} / \mathrm{l}$, which is recognised as the upper limit of normal physiological level in early lactation (Whitaker et al. 1983).
Fig. 1. When is metabolic load stressful? In this diagram the challenge to the animal is expressed as a simple function of duration and intensity of metabolic load increasing in the direction of the arrows. The dashed lines represent combinations of these two factors resulting in equal amounts of metabolic load. The bold line shows the threshold beyond which a given animal can no longer cope through behavioural and physiological adaptation (Nielsen \& Lawrence 1996).

\section{The metabolic cycle of the lactation}

A lot of the problems in managing the high yielding dairy cow start well before calving. The productive year of the cow can be divided into three phases largely dependent on the hormonal changes that occur (Holtenius 1994).

First we have a phase of catabolic reactions where body tissues are broken down. This is an obligatory hormonally controlled fat-mobilization which is to a certain extent independent of energy balance. The catabolic phase starts 2-3 weeks before calving and extends 6-12 weeks into lactation depending on how well the cow is managed and fed. After the catabolic phase, which is the most complicated period and where most of the metabolic disturbances occur, we have a 5 months period of equilibrium. After the equilibrium phase the anabolic reactions become dominant and this phase extends into the dry period.

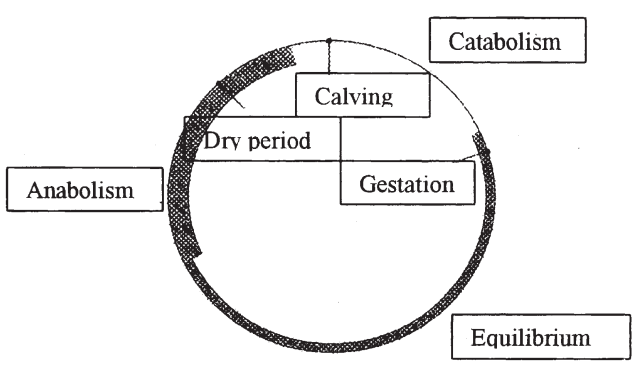

Figure 1. 


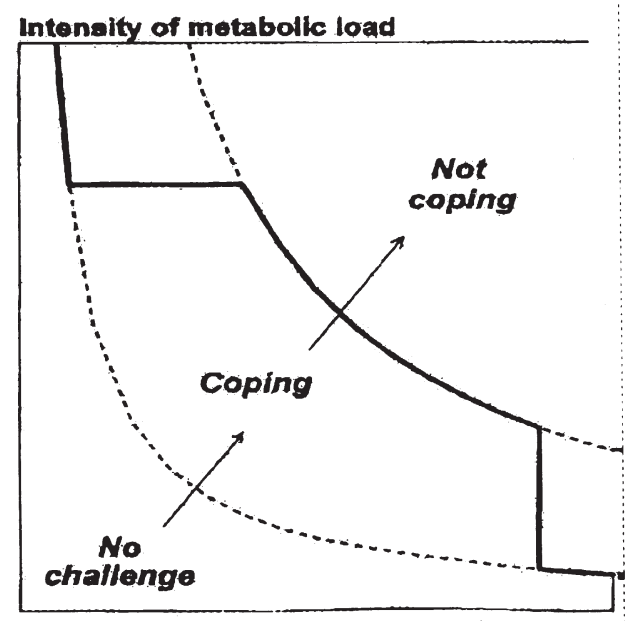

Duration of metabolic load

Figure 2. The metabolic cycle of the lactating cow.

The selection of cows for high milk production is a selection for cows with great metabolic capacity i.e. these cows can produce precursors for milk synthesis by utilizing the feed and the body reserves in an efficient manner. To a large extent the metabolic capacity means the ability of the cow to produce glucose, glucose being the main determinant of the amount of milk the cow is producing in early lactation.

\section{Voluntary food intake}

Energy intake is the first limiting factor in sustaining high yield in dairy cattle. In northern Europe and in particular Iceland, where the ration consists to a large extent on grass silage, it is vitally important that it is of high quality in order to ensure high dry matter intake. Within organic farming at least $60 \%$ of the dry matter in daily rations should consist of roughage, fresh or dried fodder, or silage. Permission can be granted for reduction to $50 \%$ for animals in dairy production for a maximum period of three months in early lactation. .

It is important to realize the physical limitations of voluntary dry matter intake, in particular in the organic system where the ration contains large amounts of roughage. Voluntary dry matter intake is affected by animal-, managementand nutritional-factors. As the digestibility of feed increases so does the dry matter intake. Maximum energy intake is achieved when large proportion of the ration (75\%) consists of concentrates (Broster et al. 1979). Supplementation with concentrates may improve intake of very poor roughage but generally it reduces roughage intake. The rate of substitution increases with increasing quality of the roughage (Broster et al. 1979).

Concentrates are necessary in dairy rations for at least two reasons. Firstly, concentrates are necessary to ensure high dry matter intake and secondly, to correct the nutritional imbalance inherent in grass silage. Large proportion of the protein in grass silage is in the form of quickly degraded protein while the carbohydrate portion is slowly fermentable. This causes imbalance in the fermentation pattern, which can only be corrected by the supply of more easily fermentable carbohydrate.

\section{Energy status in early lactation}

Bovine ketosis is a major problem on Icelandic dairy farms with incidence of about 18 treatments/100 cows/year (Hardarson 1999) compared with 2-5 treatments/100 cows in most European countries. The reason for this high incidence in Iceland can to a large extent be explained by the low energy concentration of the rations normally fed to dairy cows in Iceland, as shown by a significant correlation between ß-hydroxy-butyrate and energy status (Hardarson 1980). When it comes to comparing the incidence of clinical ketosis in organic herds and conventional herds most studies in Europe report similar (Offerhaus et al. 1994, Krutzinna et al. 1996) or even lower (Weller \& Cooper 1996, Ebbesvik 1993) incidence of clinical ketosis in 


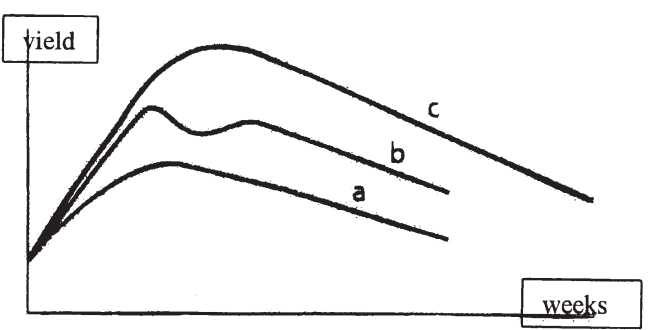

Figure 3 . The three options for the high potential dairy cow dependent on feeding and management practices. a. Cow not expressing genetic potential, b. Cow suffering clincal ketosis, c. Cow fed and managed in order to express genetic potential.

the organic herds, although herd variation is great (Vaarst 1995). Concentration of ketone bodies in blood has been studied with contradictory results. Von Weber et al. (1993) in Germany reported high incidence of hyperketonaemia without clinical cases in organic herds, while Hammarström and Hansson (1992) in Sweden and Olesen and Thuen (1996) in Norway reported low ketone levels in organic herds.

These different results are not surprising because as far as milk production and ketosis is concerned there are three options for the high potential dairy cows depending on how the cow is fed and managed. Firstly, we have well managed cows in good condition fed well balanced ration according to genetic potential reaching high yields and maintaining good health, with normal ketone levels (shown as c in the fig 3). This is what the progressive dairy farmer in the conventional system has been pursuing. Secondly, we have cows fed and prepared in the right manner during late lactation and the dry period but in early lactation the ration does not meet the requirements of the high yielding cow and consequently ketone levels are high with or without clinical ketosis and intermediate yields (shown as b in fig. 3). And thirdly, we have cows fed low digestable roughage and maintained in thin bodily condition throughout the year. By maintaining the cows in poor bodily condition at calving i.e. body score $\leq 2$, milk yield will be reduced. The level of production may also be affected by the protein:energy ratio in the feed. If the protein:energy ratio is low milk yield will be reduced. The genetic potential of these cows is not expressed, which results in low yields and apparently good health (shown as a in fig. 3). But can one say that cows enjoy good health which are experiencing suboptimal nutrition or perhaps inapparent malnutrition? Where do we place the organic dairy cow in this classification? As far as the Icelandic conditions are concerned I am afraid I have to put her into catagory $a$ or $b$. The situation may be different in countries where farmers have more feed stuffs to choose from than we do in Iceland.

\section{Discussion and conclusion}

In order to ensure animal welfare the long term solution for organic dairy farming must be to change the breeding policies in such a way that less emphasis is put on high milk yield and more emphasis on a flatter milking curve, less production diseases and longevity. The breeding programmes worldwide are increasingly becoming aware of the detrimental effects of unilateral selection for high milk yields. The Nordic countries excluding Iceland are leading the way in this instance largely due to their comprehensive national databases of individual cow health events maintained by farmers and veterinary surgeons. In Iceland the main emphasis has been on selection for high milk yields, which has lead to a steep milking curve in early lactation and high incidence of periparturient diseases. This makes the Icelandic dairy cow unsuitable for extensive farming practices. In this paper I have discussed feeding and energy status and the detrimental effects that organic or low input systems may have on the metabolic status in early lactation. It is also im- 
portant to realize that ketosis is only a part of the so-called periparturient disease complex, which includes milk fever, mastitis, retained placenta, endometritis and poor fertility, as well as bovine ketosis. All these diseases are interrelated and reflect to a large extent the nutritional status of the animal.

Although I probably fall into the group of organo-sceptics, I do realize that the organic approach is the way for agriculture to move towards more sustainable systems and away form its reliance on non-renewable resources and further intensification, and may therefore be considered as one of the alternatives for future generations, provided animal welfare is not compromised.

\section{References}

Andrews T: Suffering Animals in Green Landscape? Dairy Farmer, 1991, 38 (5) 26-28.

Broster WH, Sutton JD, Bines JA: Concentrate:Forage ratios for high yielding dairy cows. In: Recent Advances in Animal Nutrition 1978. Studies in the Agricultural and Food Sciences. Butterworth 1979.

Council Regulation (EC) No 1804/1999 of 19July 1999.

Ebbesvik M: Föring of åvdrått I ökologisk melkeproduksjon - Resultater fra 30 Bruks-prosjeketet. I: Kerner, K \& Kristensen, E.S. (eds.): Gårdstudier I ökologisk jordbrug. NJF-Udredning nr. 85. NJF-udredningsseminar, Forskningscenter Foulum, Danmark, Marts, 1993, 77-82.

Hammarström M, Hansson NE: Djurhälsostudie I mjölkbesättningar I anslutna til KRAV. Länsstyrelsen Värmlands län. Stencil 3, 1992, 16.
Hardarson GH: An investigation into bovine ketosis in Iceland and its relationship to feeding practices. Thesis submitted to MPhil degree at Edinburgh University, 1980.

Hardarson GH: Records from own practice, 1999.

Holtenius $P$ : The metabolic capacity, a factor of importance for health and production in dairy cows. Proc. XVII Nordic Vet. Congress, 1994, 185-189.

Krutzinna C, Boehncke E, Hermann HJ: Organic milk production in Germany. Biological Agriculture and Horticulture, 1996, 13, 351-358.

Nielsen $B L$, Lawrence $A B$ : Is metabolic load necessarily stressful? Proceedings to the XIX World Buiatrics Congress, 1996, 1, 79-82.

Offerhaus EJ, Baars T, Grommers FJ: Gezondheid en vruchbarheid van mlkvee op biologische bedrijven. Report by the louis Bolk Institute, Dribergen, The Netherlands, 1994.

Olesen I, Thuen E: Ketonlegemer I blod og mjölk og ketosetendens I ökologisk mjölkeproduksjon. Husdyrforsöksmöte 1996, 206-210.

Vaarst M.: Sundhedstilstand og sygdomshandtering I Danske økolgiske malkekvægbesætninger. Dansk Veterinærtidsskrift, 1995, 78, 966-970.

Vaarst M, Hindhede J, Enevoldsen C: Sole disorders in conventionally managed and organic dairy herds using different housing systems. Journal of Dairy Research, 1998, 65, 175-186.

Von Weber S, Pabst K., Schulte-Conerne H, Westphal $R$, Gravert HO: Five year studies on conversion to organic milk production. 1. Production technology. Zuchtungskunde, 1993, 65, 325-337.

Weller RF, Cooper A: The health status of dairy herds converting from conventional to organic dairy farming. Vet. Rec. 1996, 139, 141-142.

Weller RF, Bowling PJ: Health status of dairy herds in organic farming. Vet. Rec. 2000, 146, 80-81.

Whitaker DA, Smith EJ, Kelly JM: Subclinical ketosis and serum beta-hydroxybutyrate levels in dairy cattle. Brit.Vet.Rec. 1983, 133, 61-64. 